\title{
Erratum to: A call to arms for systematists: revitalising the purpose and practises underpinning the description of novel microbial taxa
}

\author{
Iain C. Sutcliffe $\cdot$ Martha E. Trujillo • \\ Michael Goodfellow
}

Published online: 8 September 2012

(C) Springer Science+Business Media B.V. 2012

\section{Erratum to: Antonie van Leeuwenhoek (2012) 101:13-20 \\ DOI 10.1007/s10482-011-9664-0}

The original article has been published incorrectly with an error in the first paragraph (2nd column) on page 18 . While the sentence published reads "notably, the 28 subcommittees of the ICSP have remits that cover only a fraction of the bacterial world (and there is no subcommittee for any archaeal taxa)".

The correct sentence should now read as "notably, the 28 subcommittees of the ICSP have remits that cover only a fraction of the bacterial world (and there are only two subcommittees for the archaeal taxa)".

The online version of the original article can be found under doi:10.1007/s10482-011-9664-0.

I. C. Sutcliffe ( $\square)$

School of Life Sciences, Northumbria University,

Newcastle upon Tyne NE1 8ST, UK

e-mail: iain.sutcliffe@northumbria.ac.uk

M. E. Trujillo

Departamento de Microbiología y Genética,

Campus Miguel de Unamuno, Universidad de Salamanca,

37007 Salamanca, Spain

M. Goodfellow

School of Biology, University of Newcastle,

Newcastle upon Tyne NE1 7RU, UK 